九州大学学術情報リポジトリ

Kyushu University Institutional Repository

Biology of Hemiptarsenus varicornis

(Hymenoptera : Eulophidae), A Parasitoid Wasp of the Leafminer Liriomyza trifolii (Diptera : Agromyzidae)

Ho, Thi Thu Giang

Institute of Biological Control, Faculty of Agriculture, Kyushu University

Ueno, Takatoshi

Institute of Biological Control, Faculty of Agriculture, Kyushu University

https://doi.org/10.5109/24458

出版情報 : 九州大学大学院農学研究院紀要. 47 (1)，pp.45-54，2002-10-30. Kyushu University バージョン:

権利関係 : 


\title{
Biology of Hemiptarsenus varicornis (Hymenoptera: Eulophidae), A Parasitoid Wasp of the Leafminer Liriomyza trifolii (Diptera: Agromyzidae)
}

\author{
Giang HO Thi Thu* and Takatoshi UENO** \\ Institute of Biological Control, Faculty of Agriculture, Kyushu University, \\ Fukuoka 812-8581, Japan \\ (Received June 28, 2002 and accepted July 12, 2002)
}

\begin{abstract}
Dipteran leafminers belonging to the family Agromyzidae are serious insect pests for many vegetable and ornamental crops in Asia including Vietnam and Japan. The parasitoid wasp Hemiptarsenus varicornis (Girault) has recently been recognized as an effective biological control agent of such leafminers including Liriomyza trifolii (Burgess) and L. bryoniae (Kaktenbach). However, the biology of $H$. varicornis is not fully understood. In this paper, we investigated development time, adult longevity, egg production and parasitism of $H$. varicomis in the laboratory, examining basic life history characteristics of this parasitoid. At a constant $25^{\circ} \mathrm{C}$ condition, females survived significantly longer than males when fed on honey solution in the absence of hosts. The mean longevity were 7 and 12 days for males and females, respectively. Development time from egg to adult emergence of males was significantly shorter than that of females (adv. 10.4 vs. 10.9 days at $25^{\circ} \mathrm{C}$ ). Dissection experiments showed that females emerged with no or only a few mature and immature eggs. Fecundity of females remained steady when no hosts were provided (2-4 mature eggs), suggesting that $H$. varicomis have to feed on hosts to enhance egg production. Cage experiments were conducted to evaluate reproductive capacity of females. The results demonstrated that female $H$. varicomis killed on average 31 leafminer larvae by parasitism during 5 consecutive days since emergence. The female showed destructive host-feeding, and killed on average 11 leafminer larvae by host-feeding in addition to by parasitism. There was a positive relationship between numbers of hosts fed upon and those parasitized, suggesting again that host-feeding related to enhancement of egg production.
\end{abstract}

\section{INTRODUCTION}

In recent years, dipteran leafminers belonging to the genus of Liriomyza of the family Agromyzidae are recognized as serious and widespread pests in Europe, America, and many Asian countries including Vietnam and Japan (e.g., Wardlow, 1985; Minkenberg and van Lenteren, 1986; Sheng et al., 1989; Spencer, 1989; Ohno et al., 1999a, b; Thang, 1999; Rauf et al., 2000). They attack numerous vegetable crops like beans, cucumber, potato and crucifers, and also a number of ornamental crops. L. sativae Blanchard may cause yield losses of up to 70\% in tomato crops (Waterhouse and Norris, 1987; Spencer, 1989). In Japan, L. trifolii (Burgess) has been one of the most serious pest leafminers since its accidental introduction. L. trifolii has historically been a major pest of a wide variety of greenhouse crops in the world (Parrella et al., 1984; Wardlow, 1985; Minken-

\footnotetext{
* Present address: Department of Entomology, Faculty of Agronomy, Hanoi Agricultural University, Trau Quy, Gia Lam, Vietnam.

** Corresponding author (E-mail: ueno@grt.kyushu-u.ac.jp)
} 
berg and van Lenteren, 1986).

In agricultural systems using frequent pesticide application, leafminers have developed resistance to pesticides quickly, and therefore, control of leafminers exclusively with pesticides is difficult (Parrella et al., 1984; Wardlow, 1985). Alternative methods such as biological control or IPM program are thus required to effectively suppress leafminer populations. Accordingly, research has been conducted to test various IPM strategies and combinations of different control methods against pest dipteran leafminers (e.g., Minkenberg and van Lenteren, 1987; Heinz and Parella, 1990; Weintraub and Horowitz, 1998; Saito et al., 1995; Ohno et al., 1999a, b; Ozawa et al., 1998, 1999, 2001; Weintraub, 2001).

So far, parasitoid Hymenoptera have proven success as agents of biological control of a variety of insect pests developing insecticide resistance (Greathead, 1986; Waterhouse and Norris, 1987). More recently, several studies have shown that biological control can be a promising method to control leafminer pests (e.g., Johnson and Hara, 1987; Parrella et al., 1987, 1989; Sheng et al., 1989; Saito et al., 1995; Ozawa et al., 2001).

Although there are many hymenopteran parasitoids attacking L. trifolii (Konishi, 1998; Arakaki and Kinjo, 1998; Ohno et al., 1999a; Ozawa et al., 2001), Hemiptarsenus varicornis (Girault) (Hymenoptera: Eulophidae), a solitary larval ectoparasitoid, is suggested to be a promising agent (Saito et al., 1995; Ozawa et al., 2001). However, relatively few studies have examined the basic biology of this parasitoid. A brief description of $H$. varicornis development time when reared on $L$. trifolii was given (Bordat et al., 1995; Saito et al., 1997). Bordat et al. (1995) provided information on parasitism of $L$. trifolli larvae of different stages (i.e., larval instars) by $H$. varicornis. However, other information such as adult longevity, fecundity etc. are lacking. Basic information about the biology of this parasitoid is still limited.

Thus, the biological characteristics of $H$. varicornis are not fully understood. Consequently in this paper, we investigated biological parameters including development time, adult longevity, egg production and reproductive capacity of $H$. varicornis in the laboratory, examining basic life history characteristics of the parasitoid. Our study provides additional information on the biology of $H$. varicomis, which may allow better use of this species as a control agent against agromizid leafminers.

\section{MATERIALS AND METHODS}

\section{Cultures}

The leafminer Liriomyza trifolii used in our study was originated from Fukuoka, Kyushu, Japan. The populations have been maintained for generations in the laboratory, by using Kidney bean plants as a host plant (Ohno et al., 1999a). The parasitoid wasp Hemiptarsenus varicornis was originated from Shizuoka, Honshu, Japan (Saito et al., 1997). Leafminers and parasitoids were mass-reared and maintained at $25 \pm 1{ }^{\circ} \mathrm{C}, 60-70 \%$ humidity under a constant light in a rearing room.

\section{General rearing procedure}

Seeds of kidney bean were planted in plastic pots $(7.5 \mathrm{~cm}$ in diameter). After one week of germination, a pan $\left(32 \mathrm{~cm}^{*} 44 \mathrm{~cm} * 6 \mathrm{~cm}\right)$ containing 24 potted plants was then 
located on a large shelf covered with a fine meshed nylon. Leafminer adults were released into the shelf for oviposition. After a $24 \mathrm{~h}$ exposure for oviposition, the potted plants were removed from the shelf and maintained at $25 \pm 1{ }^{\circ} \mathrm{C}$ until all leafminer larvae were matured. Leaves containing matured larvae were cut off from the plants, and were collected to gain adult leafminers.

Hemiptarsenus varicomis was reared on the L. trifolii. Kidney bean plants infested with large numbers of second and third instars of $L$. trifolii and female parasitoids were introduced into a transparent plastic box $(20 \mathrm{~cm} * 20 \mathrm{~cm} * 35 \mathrm{~cm})$, one side of which was covered with a fine meshed nylon. Tissue paper saturated with a $30 \%$ honey solution was also placed in the box as a food source for female parasitoids. Female parasitoids were allowed to attack and parasitized leafminer larvae for 24 hours. After 24 hours for parasitism, plants with parasitized hosts were taken away, and were kept in the rearing room for 5-7 days. Leaves containing parasitized larvae were then cut off from the plants, and were placed in a rearing plastic box $(19 \mathrm{~cm} * 25 \mathrm{~cm} * 9 \mathrm{~cm})$ for parasitoid emergence.

\section{Adult longevity}

Longevity of adult parasitoids was investigated under a laboratory condition at $25 \pm$ $1{ }^{\circ} \mathrm{C}$. Newly emerged adults were individually placed in plastic cups $(4.5 \mathrm{~cm}$ in diameter, $3.0 \mathrm{~cm}$ in height) together tissue paper saturated with a honey solution (30\%). Tissue paper was replaced daily to provide parasitoids with fresh food. Parasitoid mortality was recorded every day until all parasitoids had died. In total, 44 females and 81 males were used in this experiment.

\section{Development time}

Development time from eggs to adult emergence of $H$. varicornis was examined at a constant $25^{\circ} \mathrm{C}$ condition. Parasitized hosts were obtained as with the methods mentioned in the general rearing procedure. Potted plants with parasitized leafminers were removed from the cage after a 24-hours-exposure. The plants were maintained at $25 \pm 1{ }^{\circ} \mathrm{C}$ for 7 days in a rearing room. Then, leaves of the plants were cut off, and were placed singly in plastic cups until parasitoid emergence. The day of parasitoid emergence was recorded every day, and developmental time required from egg (oviposition) to adult parasitoid emergence in day was calculated.

\section{Egg production}

Egg production rate of $H$. varicornis was assessed in this experiment. For this purpose, dissection experiments were performed. Newly emerged females were collected and were allowed to mate with males. Mated females were placed in plastic cups $(4.5 \mathrm{~cm}$ in diameter, $3.0 \mathrm{~cm}$ in height) together with tissue paper saturated with a $30 \%$ honey solution. The cups were then kept at $20 \pm 1^{\circ} \mathrm{C}$. In this experiment, females were not allowed access to hosts.

Females of $1,2,3,4,5$ and 6 days old were dissected under a binocular microscope, and the number of mature and immature eggs a female carried were counted. A total of 36 females were used in this experiment. Mature eggs are elongate oval and opaque with the smooth surface, and can hence be distinguished from immature eggs with the rough surface. 


\section{Oviposition and host-feeding}

The aim of this experiment was to examine the potential of $H$. varicornis as a natural enemy of $L$. trifolii. For this purpose, we investigated how many leafminer larvae a female of $H$. varicornis could kill. Preliminary observations showed that $H$. varicomis killed $L$. trifolii larvae by parasitism and host-feeding, the numbers of hosts fed upon as well as those parasitized were counted.

Kidney bean plants infested with large number of second and third instars of $L$. trifolli were used in this experiment. Plants with leafminers were individually placed in a transparent plastic box (see the General rearing procedure) and then one female $H$. varicomis was carefully introduced into the box. Tissue paper saturated with a $30 \%$ honey solution was also placed in the box to provide female wasps with food.

Female $H$. varicornis was allowed to attack leafminers for 24 hours. After a $24 \mathrm{~h}$ exposure, plants were removed from the cage, and leafminers within leaf tissues were checked under a binocular microscope. Number of parasitoid eggs and leafminer age (second and third instars) were recorded. Care was taken to examine whether body fluids of host leafminers was exuded on the body surface or not. When host body fluids was found to be exuded on a host, we regarded that the host was fed upon by a female wasp.

This treatment was repeated five consecutive days; thus a total of five plants with leafminers were given to each female wasp (female age: 1-5 days). The experiment was conducted at $25 \pm 1^{\circ} \mathrm{C}$ under constant light. A total of seven females and 1383 host leafminers were used in the experiment.

\section{Data analyses}

Statistical treatments were made with the aid of StatView (SAS Institute, 1998). Normality and equal variance of data were checked, and the subsequent statistical analyses were then performed. Longevity and development time were analyzed with ANOVA or Welch's ANOVA. Regression analyses were used to analyze egg production data.

\section{RESULTS AND DISCUSSION}

\section{Longevity}

Males and females lived on average for 7.05 and 12.41 days, respectively when they were allowed to feed on a honey solution (Table 1). Parasitoid longevity differed significantly between the sexes (ANOVA, $F=5.13, P<0.05$ ); therefore females survived longer than males. In many parasitoids, life expectancy in females is nearly always greater than

Table 1. Longevity and development time of Hemiptarsenus varicomis at $25^{\circ} \mathrm{C}$

\begin{tabular}{lrc}
\hline Parasitoid sex & Longevity* & Development time* \\
\hline Male & $7.05 \pm 5.69(23)$ & $10.4 \pm 0.9(258)$ \\
Female & $12.41 \pm 7.96(25)$ & $10.9 \pm 1.0(134)$ \\
\hline
\end{tabular}

* Data were shown as mean $\pm \mathrm{SD}$. Longevity and development time in fernales were both longer than those in males (ANOVA, $\mathbf{P}<0.05$ ). Numbers in parentheses indicate sample size. 
males (e.g., Ooi, 1980; Olmi, 1994). Our study has shown that this holds true for $H$. varicornis.

Nutritional factors have been shown to be important in the modification of longevity and lifetime reproductive success in parasitoids (Leius, 1960, 1961; Syme, 1977; van Lenteren et al., 1987; Jervis et al., 1993; Jervis and Kidd, 1996; Olson et al., 2000; Schmale et al., 2001). Carbohydrate intakes cause an increase in life span of many insects (e.g. Slansky and Rodriguez, 1987). In our study, male and female H. varicomis were allowed access to a $30 \%$ honey solution. This is because when only water is provided, they die within a few days (personal observations). Thus, as with the case for many parasitoids, carbohydrate sources are important for $H$. varicomis to increase reproductive lifetime.

\section{Development time}

Mean development time of $H$. varicomis from egg to adult emergence when reared on $L$. trifolii under a constant $25^{\circ} \mathrm{C}$ was 10.4 and 10.9 days for males and females, respectively (Table 1). Based on the result of Bartlett test ( $F=3.70, P=0.054)$, Welch's ANOVA was applied to examine a mean difference between the sexes. Mean development time significantly differed between the sexes (Welch's ANOVA, $F=29.19, P<0.01$ ), and thus males developed faster than females did (Table 1).

Comparable values are reported by Saito et al. (1997) for $H$. varicomis developing on $L$. trifoli $i$; in their study, mean development time for females and males are 8.8 day and 8.6 day, respectively. The mean values appear to be smaller than those in our study. Part of the reasons may be that, in our rearing systems, humidity is low (around 60\%),

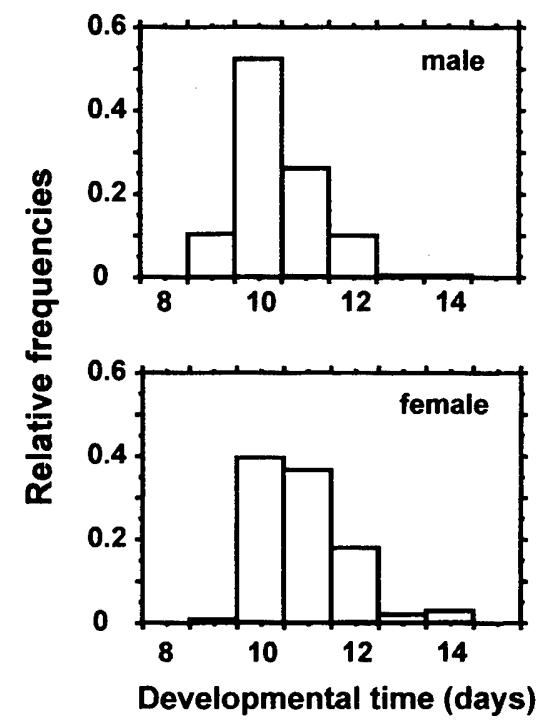

Fig. 1. Variation in development time in male and female Hemiptarsenus varicornis. 
leading to longer development time.

Male parasitoids often develop faster than females, and, hence, emerge from the host earlier. This phenomenon is called protandry, and protandry is known to exist in many insect species including most parasitic Hymenoptera (Doutt, 1964; Fagerstrom and Wiklund, 1982; Hirose et al., 1988; Quicke, 1997) as does in H. varicomis (Fig. 1).

In addition, an examination of frequency distributions of male and female development time showed that male development time varied significantly less than female development time (Kolmogorov-Smirnov test; $\mathrm{df}=2, P=0.0003$ ) (Fig. 1). Because male parasitoid wasps can usually mate many times while females of many parasitoids mate only once, shorter development time may enable a male to increase its chances of contacting virgin females.

\section{Egg production}

In the present study, we investigated fecundity of female $H$. varicornis when hosts were not given. In the condition, females had only 2-4 mature eggs with a few immature eggs in the ovary. For both mature and immature eggs, there were no significant relationships with female age (Fig. 2; Regression analysis; $\mathrm{N}=35$, $\mathrm{df}=1, r^{2}=0.02, t=0.89, P=0.38$ for mature eggs, $r^{2}=0.08, t=1.74, P=0.09$ for immature eggs). The number of mature and immature eggs remained steady between the first and sixth days after wasp emergence.

Given that female $H$. varicornis had a potential to lay more eggs in cage experiments (also see Bordat et al., 1995), the results of the dissection experiment are not consistent
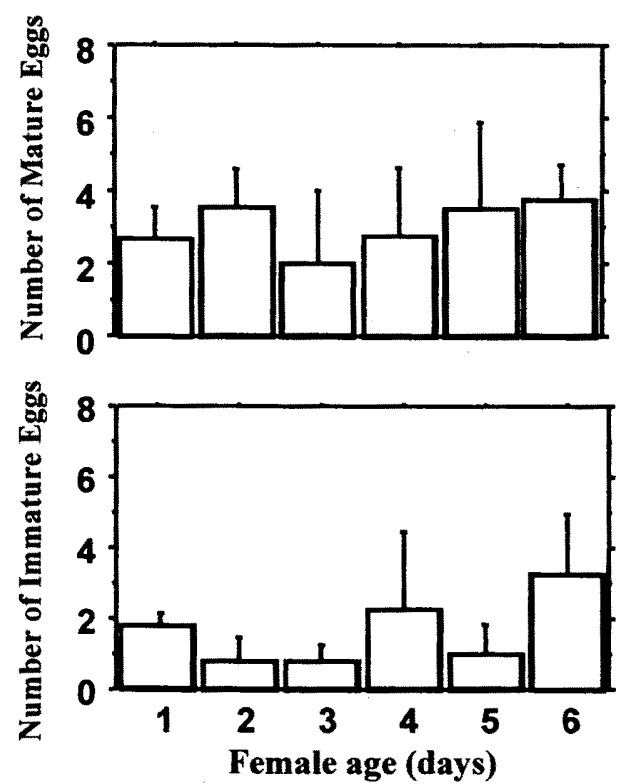

Error Bars: \pm 1 Standard Deviation

Fig. 2. Egg production by Hemiptarsenus varicomis in relation to female age. 
with the results of the oviposition and host-feeding experiment (see below). A most likely explanation is that $H$. varicomis enhances egg production in the presence of hosts. Eulophid parasitoids attacking dipteran leafminers are known to feed on hosts to produce eggs (Minkenberg and van Lenteren, 1986). Likewise, H. varicornis is said to feed on hosts. If this holds true, the maximum egg production of $H$. varicormis would be attained only when sufficient numbers of hosts are given. To test this, relationships between host-feeding behavior and egg production should be examined (see below).

\section{Oviposition and host-feeding}

Female $H$. varicornis parasitized 14-43 host leafminers during the experimental period (Table 2). The female killed 6-18 host leafminers by host-feeding (Table 2). Mean numbers of hosts parasitized and fed upon were $31.4 \pm 0.6$ and $11.4 \pm 4.9$, respectively. Mean numbers of hosts killed (i.e., \# parasitized plus \# host-fed) during the 5-day-experimental period was $42.9 \pm 14.8$.

Table 2. Numbers of hosts used for oviposition and host-feeding among seven female Hemiptarsenus varicomis in the cage experiment

\begin{tabular}{cccc}
\hline Wasp no & $\begin{array}{c}\text { No. of hosts } \\
\text { parasitized }\end{array}$ & $\begin{array}{l}\text { No. of hosts } \\
\text { fed upon }\end{array}$ & $\begin{array}{c}\text { Total no. of } \\
\text { hosts killed }\end{array}$ \\
\hline 1 & 42 & 15 & 57 \\
2 & 26 & 10 & 36 \\
3 & 34 & 6 & 40 \\
4 & 14 & 6 & 20 \\
5 & 24 & 9 & 33 \\
6 & 43 & 18 & 61 \\
7 & 37 & 16 & 53 \\
Average * & $31.4 \pm 10.6$ & $11.4 \pm 4.9$ & $42.9 \pm 14.8$ \\
\hline
\end{tabular}

* Mean values were indicated with standard deviations.

Numbers of hosts parasitized considerably varied among parasitoid individuals. The reasons were unclear. One possible factor would be variation in the size of female parasitoids. For many parasitoids, it is often found that female size closely relates to fecundity of each female (e.g. Godfray, 1994; Quicke, 1997). In our study, unfortunately, the size of test females was not measured.

Because larger individuals are generally more fecund and have longer life span, larger individuals are more likely to work better as a biocontrol agent. If this is the case for $H$. varicomis, production of large females will be required during mass-rearing process. Factors affecting the size of $H$. varicomis and the relationship between female size and fecundity should be examined in the future study.

H. varicormis killed considerable numbers of hosts by host-feeding (Table 1). There was a significant relationship between total numbers of hosts fed upon and those parasitized (Fig. 3) (Regression analysis: $\mathrm{N}=7, r^{2}=0.63, t=2.89, P=0.034$ ). This result suggests that females that feed more can parasitize more. Host-feeding is an essential means of obtaining protein sources for a number of parasitoid wasps, and feeding activities 


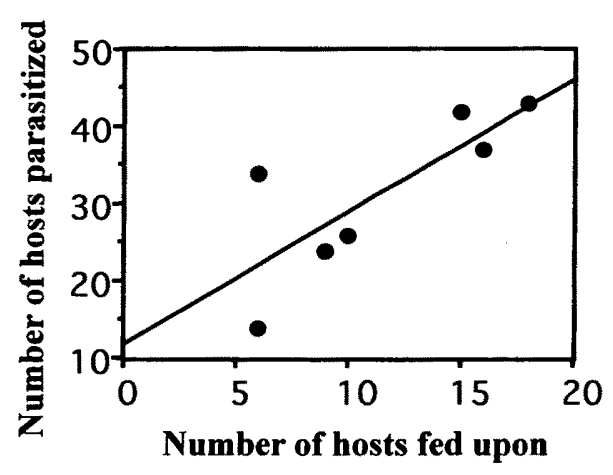

Fig. 3. Relationship between the numbers of host-feedings and ovipositions in Hemiptarsenus varicornis.

correlate to female fecundity (e.g. Leius, 1961; van Lenteren et al., 1987; Jervis and Kidd, 1996; Morales-Ramos et al., 1996; Ueno, 1999). This is the case for H. varicornis.

The result also suggests that about $60 \%$ variations in numbers of hosts parasitized by each test female can be explained by differences in numbers of hosts each test female feed on. However, why there is a variation in numbers of hosts fed upon remains unsolved. Again, relationships between female size and host-feeding should be investigated.

\section{ACKNOWLEDGEMENTS}

We thank Dr. K. Ogata at Institute of Tropical Agriculture, Kyushu University for his support and encouragement, and Mrs. Y. Ayabe for practical assistance in rearing of the insects. We also thank Drs. A. Ozawa (Shizuoka Agricultural Experimental Station) and E. Yano (National Agricultural Research Center) for providing us with H. varicomis, and Dr. K. Ohno (Miyazaki University) for his kind supply L. trifolii. Finally, we are grateful to Dr. M. Takagi at Institute of Biological Control, Kyushu University for his continuous support.

\section{REFERENCES}

Arakaki, N. and K. Kinjo 1998 Notes on the parasitoid fauna of the serpentine leafminer Liriomyza trifolii (Burgess) (Diptera: Agromyzidae) in Okinawa, southern Japan. Appl. Entomol. Zool., 33: $577-581$

Bordat, D., E. V. Coly and C. Roux-Olivera 1995 Morphometric, biological and behavioral differences between Hemiptarsenus varicomis (Hym., Eulophidae) and Opius dissitus (Hym., Braconidae) parasitoids of Liriomyza trifolii (Dip., Agromyzidae). J. Appl. Entomol., 119: 423-427

Doutt, R. L. 1964 Biological characteristics of entomophagous adult. In "Biological Control of Insect Pests and Weeds", Rheinhold, New York, pp. 145-167

Fagerstrom, T. and C. Wiklund 1982 Why do males emerge before females? Protandry as a mating strategy in male and female butterflies. Oecologia, 52: 164-166

Godfray, H. C. J. 1994 Parasitoids: Behavioral and Evolutionary Ecology. Princeton University Press, New Jersey 
Greathead, D. J. 1986 Parasitoids in classical biological control. In "Insect Parasitoids", 13" Symp. Royal Entomol. Soc. London, 18-19 September 1985. London

Hirose, Y., S. B. Vinson and Y. Hirose 1988 Protandry in the parasitoid Cardiochiles nigriceps as related to its mating system. Ecol. Res., 3: 217-226

Jervis, M. A., N. A. C. Kidd, T. Fitton, T. Huddleston and H. A. Dawah 1993 Flower visiting by hymenoptera parasitoids. J. Nat. Hist., 27: 67-105

Jervis, M. A. and N. A. C. Kidd 1996 Phytophagy. In "Insect natural enemies: practical approaches to their study and evaluation", ed. by M. A. Jervis and N. A. C. Kidd, Chapman and Hall, London, pp. 375-394

Johnson, M. W. and A. H. Hara 1987 Influence of host crop on parasitoids (Hymenoptera) of Liriomyza spp. (Diptera: Agromyzidae). Environ. Entomol., 16: 339-344

Heinz, K. M. and M. P. Parrella 1990 Holarctic distribution of the leafminer parasitoid Diglyphus begini (Hymenoptera: Eulophidae) and notes on its life history attacking Liriomyza trifolii (Diptera: Agromyzidae) in Chrysanthemum. Ann. Entomol. Soc. Am, 88: 916-924

Konishi, K. 1998 An illustrated key to the hymenopterous parasitoids of Liriomyza trifolii in Japan. Miscellaneous Publication of the National Institute of Agroenviromental Science, 22: 27-76 (In Japanese)

Leius, K. 1960 Attractiveness of different foods and flowers to the adults of some hymenopterous parasites. Can. Entomol., 92: 369-376

Leius, K. 1961 Influence of food on fecundity and longevity of adult of Itoplectis conquisitor (Say) (Hymenoptera: Ichneumonidae). Can. Entomol., 93: 771-780

Minkenberg,O. P. J. M and J. C. van Lenteren 1986 The leafminer Liriomyza bryoniae and L. trifolii (Diptera: Agromyzidae), their parasites and host plants: A review. Agric. Univ. Wagen. Pap., 86: $1-50$

Morales-Ramos J. A., M. G. Rojas and E. G. King 1996 Significance of adult nutrition and oviposition experience on longevity and attainment of full fecundity of Catolaccus grandis (Hymenoptera: Pteromalidae). Ann. Entomol. Soc. Am., 89: 555-563

Olmi, M. 1994 The Drynidae and Embolemidae (Hymenoptera: Chrysidoidea) of Fennoscandia and Denmark. In "Fauna Entomologia Scandinavica", Vol. 30, ed. By E.J. Brill, Leiden

Olson, D. M., H. Fadamiro, J. G. Lundgren and G. E. Heimpel 2000 Effects of sugar feeding on carbohydrate and lipid metabolism in a parasitoid wasp. Physiol. Entomol., 25: 17-26

Ooi, P. A. C. 1980 Laboratory studies of Diadegma cerophagus (Hym.: Ichneumonidae), a parasite introduced to control Plutella xylostella (Lep.: Hyponomeutidae) in Malaysia. Entomol., 25 249-259

Ohno, K., T. Ohmori and H. Takemoto 1999a Effect of insecticide applications and indigenous parasitoids on population trends of Liriomyza trifolii in gerbera greenhouses. Jap. J. Appl. Entomol. Zool., 43: 81-86

Ohno, K, K. Takesaki, D. Yamaguchi and H. Takemoto 1999b Effects of milbemectin acaricide on mortality rate of agromyzid leafminer, Liriomyza trifolii (Burgess), and its larval parasitoid, Diglyphus isaea (Walker) (Hymenoptera : Eulophidae). Jap. J. Appl. Entomol. Zool., 43: 93-97 (in Japanese with English summary)

Ozawa, A., T. Saito and F. Ikeda 1998 Effects of pesticides on Diglyphus isaea (Walker) and Dacnusa sibirica Telenga, parasitoids of Liriomyza trifolii (Burgess). Jap. J. Appl. Entomol. Zool., 42: 149-161 (in Japanese with English summary)

Ozawa, A., T. Saito and M. Ota 1999 Biological control of American serpentine leafminer, Liriomyza trifolii (Burgess), on tomato in greenhouses by parasitoids I. Evaluation of biological control by release of Diglyphus isaea (Walker) in experimental greenhouses. Jap. J. Appl. Entomol. Zool., 43 161-168 (in Japanese with English summary)

Ozawa, A., T. Saito and M. Ota 2001 Biological control of the American serpentine leafminer, Liriomyza trifolii (Burgess), on tomato in greenhouses by parasitoids II. Evaluation of biological control by Diglyphus isaea (Walker) and Dacnusa sibirica Telenga in commercial greenhouses. Jap. J. Appl. Entomol. Zool., 45: 61-74 (in Japanese with English summary)

Parrella, M. P., C. B. Keil and J. G. Morse 1984 Insecticide resistance in Liriomyza trifolii. Calif. Agric., 38: $22-23$

Parrella, M. P., V. P. Jones and G. D. Christie 1987 Feasibility of parasities for biological control of 
Liriomyza trifolii (Diptera: Agromyzidae) on commercially grown chrysanthemum. Environ. Entomol., 16: 832-837

Parrella, M. P., J. T. Yost, K. M. Heinz and G. W. Ferrentino 1989 Mass- rearing of Diglyphus begini (Hymenoptera: Eulophidae) for biological control of Liriomyza trifolii (Diptera: Agromyzidae). $J$. Econ. Entomol, 82: 420-425

Rauf, A., B. M. Shepard and M. W. Johnson 2000 Leafminers in vegetables, ornamental plants amd weeds in Indonesia: Surveys of host crops, species composition and parasitoids. Int. J. Pest Manage, 46: 257-266

Quicke, D. L. J. 1997 Parasitic Wasps. Chapman and Hall, London

Saito T., A. Ozawa and F. Ikeda 1995 The evaluation of two imported hymenopteran parasites as biological control agents for the serpentine leafminer, Liriomyza trifolii (Burgess). Proc. Kanto Pl. Prot. Soc., 42: 235-237 (in Japanese)

Saito T., A. Ozawa and F. Ikeda 1997 Development time of Ectoparasitoid, Hemiptarsenus varicomis on Liriomyza trifolii and L. bryoniae. Jap. J. Appl. Entomol. Zool., 41: 161-163 (in Japanese with English summary)

Schmale 1., F. L. Wackers, C. Cardona and S. Dorn 2001 Control potential of three hymenoptera parasitoid species against the been weevil in stores beans: The effect of adult parasitoid nutrition on longevity and progeny production. Biol. Control., 21: 134-139

Sheng, J. K., L. Zhong and Q. Wu 1989 The hymenopterous species of parasites of Phytomyza horticola Gourea from Jiangxi Provice in China. Acta Agric. Universitatis Jiangxiensis, 39: 22-31

Slansky Jr, F. and J.G. Rodriguez 1987 Nutritional Ecology of Insects, Mite, Spiders and related Invertebrates. Wiley, New York

Spencer, K. A. 1989 Leafminer. In "Plant Protection and Quarantine Vol II. Selected Pests and Pathogens of Quarantine Significant", CRC Press, Inc., Boca Raton, Florida, USA, pp. 77-98

Syme, P. D. 1977 Observation on the Iongevity and fecundity of Orgilus obscurator (Hymenoptera: Braconidae) and the effects of certain foods on longevity. Can. Entomol., 109: 995-1000

Ueno, T. 1999 Reproduction and host-feeding in the solitary parasitoid wasp Pimpla nipponica (Hymenoptera: Ichneumonidae). Inverteb. Reprod. Develop. 35: 231-237

Thang, V. T. 1999 Surveys of leafminers (Liriomyza) and their parasitoids on vegetable in Vietnam 1998. In "Workshop on leafminers of Vegetables in Southeast Asia, 2-5 February 1999, Heritage Hotel, Tanah Rata, Cameron Highlands", ed. by Lim Guan Soon, Soetikno S. Sastroutomo and Loke Wai Hong, Malaysia

van Lenteren, L. C., A. van Vianen, H. F. Gast and A. Kortenhoff 1987 The parasite- host relationship between Encarsia formosa Gahan (Hymenoptera: Aphelinidae) and Trileurodes vaporariorum (Westwood) (Homoptera: Aleyrodidae). Z. angew. Entomol., 103: 69-84

Wardlow, L. R. 1985 Control of leafminer on Chrysanthemums and tomatoes by parasites. In "Biological Pest Control: the Glasshouse Experience", Cornell Univ. Press, Ithaca, N.Y., pp. 129-133

Waterhouse, D. F. and K. R. Norris 1987 Biological control: Pacific Propspects. Ikata Press, Melborne, Australia

Weintraub, P. G. 2001 Effects of cyromazine and abamectin on the leafminer, Liriomyza huidobrensis and its parasitoid, Diglyphus isaea in potatoes. Crop Prot., 20: 207-213

Weintraub, P. G. and A. R. Horowitz 1998 Effects of translaminar versus conventional insecticides on Liriomyza huidobrensis (Blanchard) (Ditera: Agromyzidae) and Diglyphus isaea Walker (Hymenoptera: Eulophidae) populations in celery. J. Econ. Entomol., 91:1180-1185 